\title{
Analisis Indeks Pembangunan Manusia Provinsi-Provinsi di Indonesia Menggunakan Indeks Baru Berdasarkan Metode Resampling
}

\author{
Elsa Septyana ${ }^{1, *}$, Adi Setiawan $^{1}$, Bambang Susanto ${ }^{1}$ \\ ${ }^{1}$ Program Studi Matematika, Fakultas Sains dan Matematika, Universitas Kristen Satya Wacana, Salatiga, \\ Jawa Tengah 50711 \\ *email korespondensi: septyanaelsa@gmail.com
}

Received : 7 Januari 2021; Revised : 28 Februari 2021; Accepted : 2 Maret 2021; Published : 1 April 2021

\begin{abstract}
ABSTRAK
Pada penelitian ini dibahas tentang penggunaan Indeks Baru untuk mengukur autokorelasi spasial secara global. Kontribusi utama dari karya ini adalah untuk mengetahui korelasi antara Indeks Geary dan Indeks Moran. Selain itu penelitian ini bertujuan untuk mengetahui pengaruh spasial terhadap IPM Provinsi-Provinsi di Indonesia. Data yang digunakan adalah data IPM provinsi-provinsi di Indonesia tahun 2010 - 2018. Prosedur yang dilakukan adalah dengan mengukur data IPM menggunakan Indeks Geary dan Indeks Moran. Selanjutnya nilai Indeks Geary dan Indeks Moran digunakan untuk mencari korelasi yang terjadi antara Indeks Geary dan Indeks Moran. Korelasi yang terbentuk antara Indeks Geary dan Indeks Moran sangat kuat sehingga Indeks Baru dapat dirumuskan. Untuk memvalidasi keakuratan Indeks Baru dilakukan uji autokorelasi spasial terhadap Indeks Baru menggunakan Metode Bootstrap dan resampling berdasarkan estimasi densitas Kernel. Berdasarkan hasil resampling menggunakan metode bootstrap dan resampling berdasarkan estimasi densitas Kernel dengan pengulangan sebanyak 10000 kali ditemukan bahwa nilai-p tahun 2010 - 2018 berkisar antara 0,001 - 0,006 yang berarti terdapat autokorelasi spasial atau terdapat keterkaitan erat antara IPM provinsi dengan IPM provinsi-provinsi yang bertetangga. Dengan kata lain, bahwa antar provinsi satu dengan provinsi yang berbatasan memiliki kemiripan nilai IPM atau saling berkorelasi. Dengan didapatkannya hasil analisis ini, maka dapat menjadi acuan pemerintah dalam melakukan pemerataan pembangunan disetiap provinsi di Indonesia dengan mempertimbangkan keterkaitan antar provinsi di Indonesia.
\end{abstract}

Kata-kata kunci: autokorelasi spasial; estimasi densitas Kernel; Indeks Baru; metode Bootstrap

\section{PENDAHULUAN}

Dalam perjalanan menuju negara maju, salah satu hal yang dilakukan oleh pemerintah Indonesia adalah dengan menggalakkan pembangunan seutuhnya di wilayah Indonesia. Pembangunan dalam hal ini merupakan pembangunan secara manusia batin (spirit) ataupun pembangunan secara lahir (infrastruktur). Perkembangan suatu pembangunan tidak hanya dapat dilihat satu atau dua kali peninjauan namun harus dilihat dalam jangka panjang. Untuk melihat perkembangan pembangunan dalam jangka panjang, digunakan indikator yang disebut dengan Indeks Pembangunan Manusia (IPM). IPM memiliki 3 dimensi utama yaitu dimensi umur panjang dan hidup sehat, dimensi pengetahuan, dan dimensi standar hidup layak (BPS, 2015).

Pemerataan pembangunan di wilayah Indonesia saat ini menjadi isu hangat bagi pemerintah dan masyarakat Indonesia. Indonesia merupakan negara kepulauan yang pulau-pulaunya banyak dipisahkan oleh wilayah perairan menjadikan kesenjangan pembangunan manusia antar provinsi menjadi relatif tinggi. Salah satu penelitian yang membahas tentang IPM adalah analisis IPM Kabupaten/Kota di Provinsi Maluku Utara menggunakan Indeks Geary berdasarkan resampling Estimasi Densitas Kernel (Sarita dkk., 2019). Data yang digunakan ialah data IPM Kabupaten/Kota di Provinsi Maluku Utara tahun 2013 - 2017. Hasilnya menyatakan bahwa terdapat autokorelasi spasial pada IPM Kabupaten/Kota di Provinsi Maluku Utara tahun 2013 - 2017. Penelitian tersebut juga mengidentifikasi bahwa Geary tidak berdistribusi normal.

Penelitian serupa dilakukan Nisa (2017) tentang identifikasi pola spasial dan autokorelasi spasial pada IPM di Provinsi Papua Barat tahun 2012. Penelitian dengan menggunakan Indeks Moran dan Indeks Geary ini menyatakan bahwa nilai IPM tidak mengelompok dan tidak ada keterkaitan spasial antar Kabupaten/Kota di Papua Barat. 
Penelitian lain dilakukan oleh Weku dkk. (2012) tentang identifikasi pola spasial dan dinamika IPM di Sulawesi Utara tahun 2006 - 2009 menggunakan Indeks Moran dan Indeks LISA. Penelitian ini memiliki luaran yaitu peta choropleth, Moran Scatterplot dan peta LISA. Dari luaran tersebut menyimpulkan bahwa pola kluster kecamatan yang terjadi adalah menggerombol/memusat di suatu tempat tertentu dan tidak terjadi pola acak kluster kecamatan. Hal ini berarti bahwa tidak terjadi pemerataan pembangunan manusia di Provinsi Sulawesi Utara, hal ini disebabkan karena IPM yang tinggi membentuk kelompok sendiri. Demikian pula dengan IPM yang rendah membentuk kelompoknya sendiri.

Berdasarkan penelitian sebelumnya dapat diketahui autokorelasi spasial/keterkaitan antar Kabupaten/Kota di Maluku Utara berkaitan dengan nilai IPM menggunakan Indeks Geary. Pada penelitian ini juga akan dibahas mengenai autokorelasi spasial / keterkaitan IPM antar provinsi di Indonesia namun dengan mengkaji Indeks Geary dan Indeks Moran untuk membentuk Indeks Baru berdasarkan metode resampling. Data yang digunakan adalah data IPM provinsi-provinsi di Indonesia pada tahun 2010-2018.

\section{EKSPERIMEN}

\section{Instrumen Penelitian}

Data yang digunakan yaitu data Indeks Pembangunan Manusia (IPM) provinsi-provinsi di Indonesia pada tahun 2010-2018 yang merupakan data sekunder yang diperoleh dari laman Badan Pusat Statistik (ipm.bps.go.id).

\section{Prosedur Kerja}

Data yang telah diperoleh kemudian ditentukan matriks pembobot spasialnya. Matriks pembobot spasial digunakan untuk mengetahui hubungan kedekatan antar suatu wilayah/lokasi. Matriks pembobot spasial biasanya berukuran persegi dan disimbolkan dengan $\boldsymbol{C}$ (Modjo, 2018). Elemen-elemen $\boldsymbol{C}$ memiliki dua nilai yaitu $c_{i j}=0$ untuk wilayah yang tidak bertetangga dengan wilayah pengamatan dan $c_{i j}=1$ untuk wilayah yang bertetangga dengan wilayah pengamatan (Griffith, 1996). Selanjutnya matriks pembobot spasial ditranformasi menjadi matriks pembobot spasial terstandardisasi yang disimbolkan dengan $\boldsymbol{W}$. Persamaan (1) menyatakan rumus untuk mentransformasikan matriks pembobot spasial menjadi matriks pembobot spasial terstandardisasi.

$$
w_{i j}=\frac{c_{i j}}{\sum_{j} c_{i j}} .
$$

Tujuan dari tes autokorelasi spasial ialah untuk mengetahui apakah nilai dari variabel pada satu lokasi bergantung pada nilai-nilai variabel di lokasi yang berdekatan/bertetangga (Zhukov, 2010). Pengukuran autokorelasi spasial dapat dilakukan dengan 2 cara, yaitu autokorelasi spasial global dan autokorelasi spasial lokal. Pengujian autokorelasi spasial global dapat menggunakan Indeks Moran, Indeks Geary dan Getis Ord, sedangkan untuk pengujian autokorelasi spasial lokal dapat menggunakan Local Indicators of Spatial Association (LISA). Makalah ini menggunakan autokorelasi spasial global dengan menggunakan Indeks Geary dan Indeks Moran. Hal ini dikarenakan Indeks Geary dan Indeks Moran memiliki beberapa karakteristik umum, tetapi sifat statistik saja yang berbeda (Jay \& Wong, 2000). Indeks Geary dan Indeks Moran didefinisikan sebagai berikut (Jay \& Wong, 2000):

$$
\begin{gathered}
C=\frac{(n-1) \sum_{i=1}^{n} \sum_{j=1}^{n} w_{i j}\left(x_{i}-x_{j}\right)^{2}}{2 \sum_{i=1}^{n} \sum_{j=1}^{n} w_{i j} \sum_{i=1}^{n}\left(x_{i}-\bar{x}\right)^{2}} \\
I=\frac{n \sum_{i=1}^{n} \sum_{j=1}^{n} w_{i j}\left(x_{i}-\bar{x}\right)\left(x_{j}-\bar{x}\right)}{\sum_{i=1}^{n} \sum_{j=1}^{n} w_{i j} \sum\left(x_{i}-\bar{x}\right)^{2}}
\end{gathered}
$$

Dimana $n$ menyatakan banyaknya wilayah pengamatan, $x_{i}$ menyatakan nilai pada wilayah $i, x_{j}$ menyatakan nilai pada wilayah $j$ dan $w_{i j}$ menyatakan elemen matriks pembobot spasial terstandardisasi wilayah $i$ terhadap wilayah $j$. 
Indeks Baru merupakan indikator pengujian autokorelasi spasial yang didapatkan dari hasil analisis antara Indeks Geary dan Indeks Moran. Untuk menentukan Indeks Baru langkah awal yang dilakukan ialah dengan mencari korelasi antara Indeks Geary dan Indeks Moran. Selanjutnya Indeks Baru dirumuskan sebagai berikut:

1. Mencari batas Indeks Moran dan Indek Geary

$$
\begin{gathered}
-1 \leq I_{M} \leq 1 \\
0 \leq I_{G} \leq 2 .
\end{gathered}
$$

2. Membuat batas pada Indeks Geary menjadi $-1 \leq x \leq 1$, maka Indeks Geary menjadi,

$$
\begin{gathered}
0 \leq I_{G} \leq 2 \\
-2 \leq-I_{G} \leq 0 \\
1-2 \leq 1-I_{G} \leq 1-0 \\
-1 \leq 1-I_{G} \leq 1 .
\end{gathered}
$$

3. Menjumlahkan Persamaan (4) dan Persamaan (5), menjadi,

$$
-2 \leq I_{M}+1-I_{G} \leq 2 \text {. }
$$

4. Membagi dua Persamaan (6), sehingga didapat persamaan (7) yang merupakan rumus dari Indeks Baru.

$$
-1 \leq \frac{I_{M}+1-I_{G}}{2} \leq 1 \text {. }
$$

Metode Bootstrap merupakan metode resampling yang dilakukan dengan cara pengembalian dari sampel asli. Pengembalian sampel terhadap sampel awal satu persatu dengan pengembalian dan prosedur tersebut diulang sebanyak bilangan besar $B$ kali. Selanjutnya nilai- $p$ dapat ditentukan dengan,

$$
\text { nilai }_{-p}=\frac{\left(T_{i}^{*}>T_{a w a l}\right)}{B} .
$$

dimana $i=1,2,3, \ldots, B$ dan $T_{\text {awal }}=$ nilai statistik uji berdasarkan sampel awalnya.

Uji autokorelasi spasial juga dapat dilakukan menggunakan resampling berdasarkan estimasi densitas Kernel. Diberikan sampel acak $X_{1}, X_{2}, \ldots, X_{n}$ didapat dari fungsi densitas $f$ yang tidak diketahui. Maka untuk menghitung estimasi fungsi densitas Kernel digunakan rumus sebagai berikut (Gramacki, 2018):

$$
\hat{f}(x, h)=\frac{1}{n h} \sum_{i=1}^{n} K\left(\frac{x-X_{i}}{h}\right)
$$

dimana $n$ menyatakan jumlah sampel, $h$ menyatakan bandwidth optimal dan $K$ menyatakan fungsi Kernel.

Selanjutnya dalam fungsi Kernel normal untuk memilih bandwidth $h$ optimal digunakan rumus sebagai berikut (Zucchini, 2003):

$$
h_{\text {opt }}=\left(\frac{4}{3 n}\right)^{1 / 5} \sigma
$$

dengan $\sigma$ adalah simpangan baku dan didapatkan dari data.

Berdasarkan estimasi densitas Kernel langkah-langkah untuk melakukan resampling atau membangkitkan sampel baru adalah sebagai berikut (Setiawan, 2002):

1) Diketahui sampel dengan ukuran $n$ yaitu $X_{1}, X_{2}, \ldots, X_{n}$.

2) Digunakan bandwidth optimal untuk melakukan estimasi densitas Kernel berdasarkan $X_{1}, X_{2}, \ldots, X_{n}$.

3) Sampel $X_{i}^{*}=X_{i 1}{ }^{*}, X_{i 2}{ }^{*}, \ldots, X_{i n}{ }^{*}$ dibangkitkan di sekitaran $X_{i}$ dengan membangkitkan sampel yang berukuran 1 dari distribusi normal dengan rata-rata $X_{i}$ dan variansinya yaitu bandwidth $h$ optimal.

4) Sampel baru $X_{i}^{*}$ digunakan untuk menghitung nilai masing-masing indeks dengan $I b_{i}=I b\left(X_{i}^{*}\right)$ serta $i=$ $1,2, \ldots, B$ dan $B$ dipilih secara bebas.

5) Indeks yang diperoleh sebanyak $B$ yaitu $I b_{1}, I b_{2}, \ldots, I b_{B}$ untuk Indeks Baru.

Dalam hal ini $X_{1}, X_{2}, \ldots, X_{n}$ adalah data IPM Provinsi-Provinsi di Indonesia dan $n=34$ yaitu banyaknya provinsi yang ada di Indonesia. Langkah-langkah yang digunakan untuk pengolahan data adalah sebagai berikut:

1. Menentukan peta Indonesia

2. Membuat matriks pembobot queen dengan menentukan matriks pembobot spasial dan membuat matriks pembobot spasial terstandardisasi. 
3. Menentukan Indeks Baru.

4. Melakukan pengujian autokorelasi spasial.

5. Melakukan resampling berdasarkan estimasi densitas Kernel.

\section{HASIL DAN DISKUSI}

\section{Hasil Analisis Awal}

Data IPM provinsi-provinsi di Indonesia yang berasal dari Badan Pusat Statistik tersebut diolah sehingga dapat diketahui korelasi antara Indeks Geary dan Indeks Moran yang selanjutnya dapat ditentukan model dari Indeks Baru. Gambar 1 menunjukkan Scatter Plot yang menyatakan korelasi antara Indeks Geary dan Indeks Moran. Dalam hal ini Scatter Plot dibuat dengan menggunakan bantuan Microsoft Office Excel.

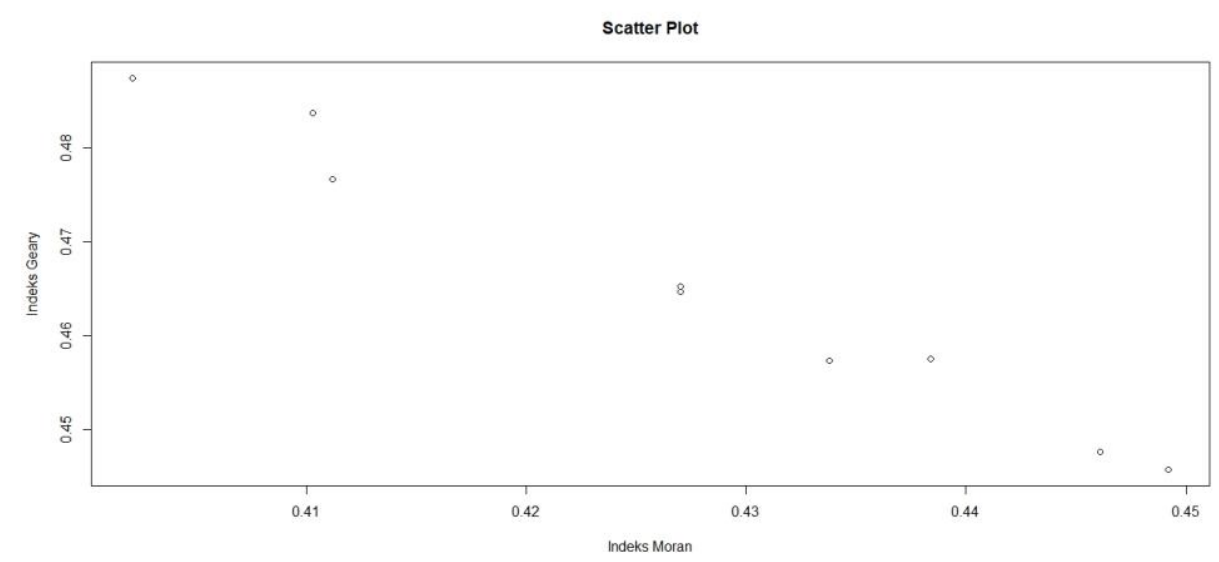

Gambar 1. Scatter Plot antara Indeks Geary dan Indeks Moran

Gambar 1 memperlihatkan hubungan/korelasi antara Indeks Moran dan Indeks Geary sangat kuat. Hal ini terbukti dengan terbentuknya titik-titik plot yang terbentuk menyerupai garis linear. Korelasi yang terbentuk merupakan korelasi yang negatif yang berarti bahwa jika nilai Indeks Geary semakin besar maka nilai Indeks Moran semakin rendah dan berlaku sebaliknya.

Kategori IPM terbagi atas empat kategori, yaitu "sangat rendah" : IPM $<60$, "rendah" : $60 \leq$ IPM $<70$, "tinggi" : $70 \leq$ IPM < 80 dan "sangat tinggi" : IPM $\geq 80$. Gambar 2 dan Gambar 3 memperlihatkan persebaran IPM menurut kategorinya untuk nilai IPM berturut-turut tahun 2010 dan 2018. Peta persebaran IPM dibuat dengan melihat nilai IPM per provinsi di Indonesia yang kemudian diolah dengan menggunakan aplikasi CorelDraw sehingga didapatkan peta persebaran IPM per provinsi di Indonesia.

\section{PETA IPM INDONESIA 2010}

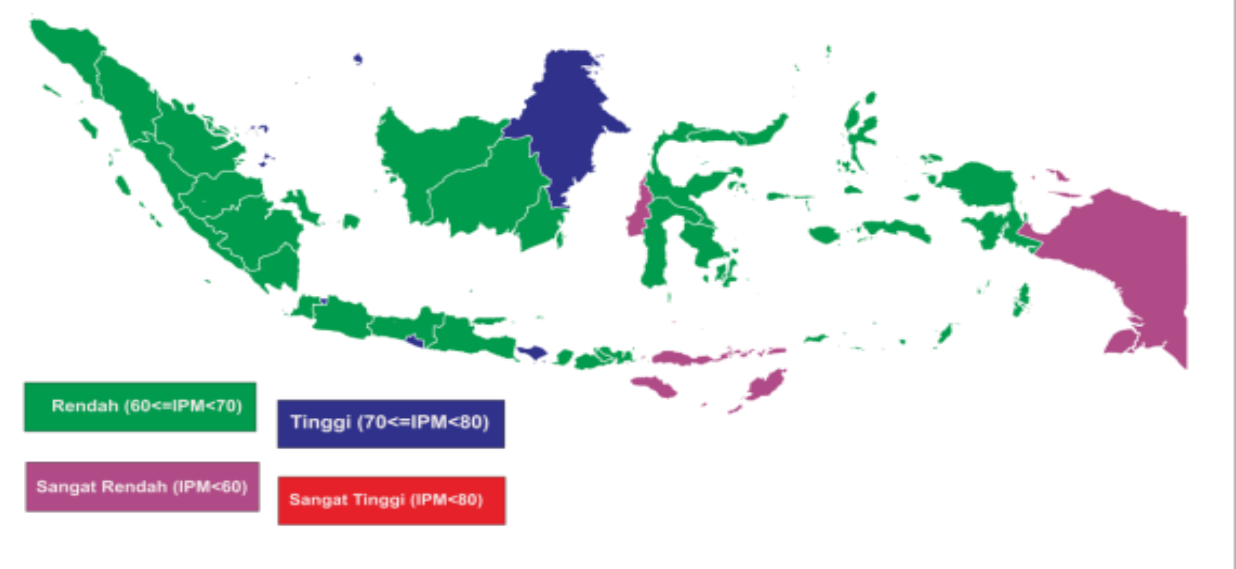

Gambar 2. Peta persebaran IPM di Indonesia per Provinsi Tahun 2010 (sumber: gambar pribadi)

Gambar 2 memperlihatkan bahwa IPM provinsi-provinsi di Indonesia berada pada warna hijau yang berarti bahwa nilai IPMnya masih dalam kategori rendah atau nilai IPM berkisar antara $60-70$. Selain itu untuk Provinsi Papua, Papua Barat, Nusa Tenggara Barat dan Sulawesi Barat memiliki nilai IPM 
dalam kategori sangat rendah. Namun untuk Provinsi DKI Jakarta, DIY, Bali dan Kalimantan Utara memiliki nilai IPM dalam kategori tinggi.

\section{PETA IPM INDONESIA 2018}

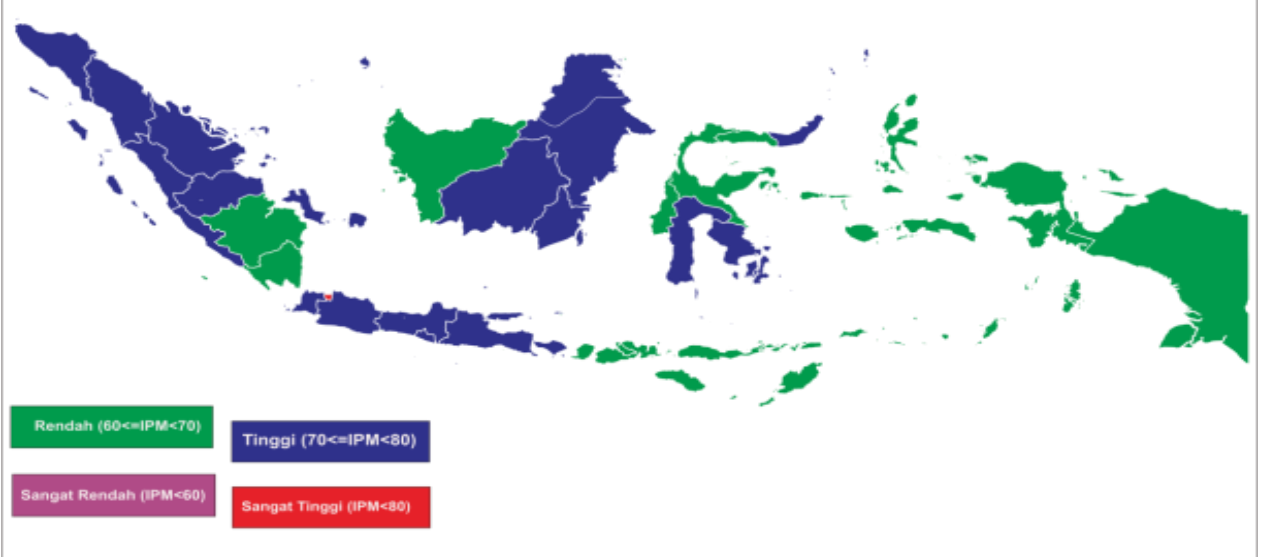

Gambar 3. Peta persebaran IPM di Indonesia per Provinsi Tahun 2018 (sumber: gambar pribadi)

Gambar 3 menunjukkan bahwa nilai IPM provinsi-provinsi di Indonesia tahun 2018 mengalami kenaikkan dibandingkan tahun 2010. Banyak provinsi di Indonesia yang sudah berada dalam kategori tinggi yang ditunjukkan dengan warna biru. Provinsi-provinsi yang tahun 2010 masih dalam kategori sangat rendah, pada tahun 2018 menunjukkan peningkatan dengan berada pada kategori rendah. Selain itu pada tahun 2018 terdapat provinsi yang sudah mencapai kategori IPM sangat tinggi yaitu Provinsi DKI Jakarta.

2. Peta

Penelitian ini menggunakan Peta wilayah Indonesia berdasarkan provinsi-provinsinya yang berfungsi untuk menentukan batas-batas antar wilayah/lokasi sehingga akan diketahui ketetanggaan antar provinsi di Indonesia. Perhatian penelitian ini adalah untuk 34 provinsi di Indonesia yang ditunjukkan pada Gambar 4.

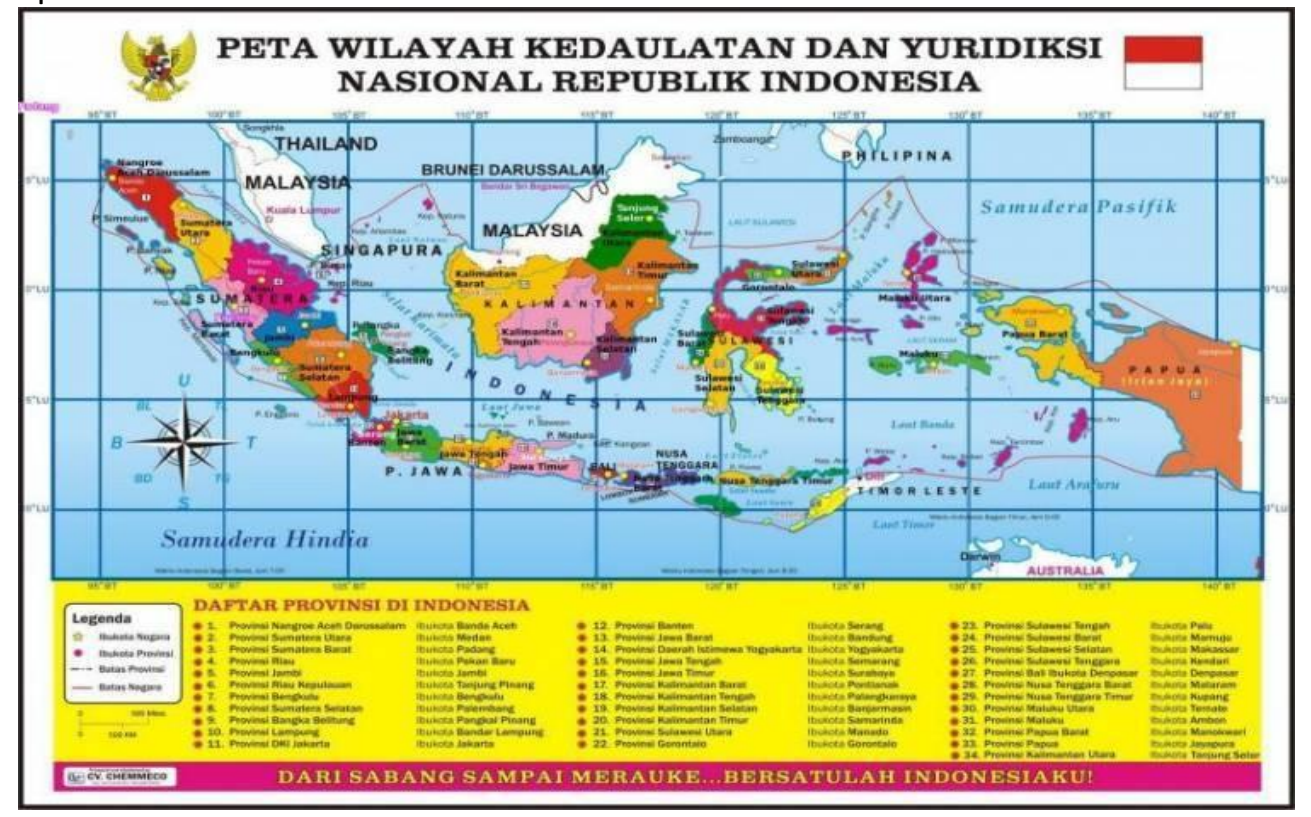

Gambar 4. Peta Indonesia berdasarkan Provinsi (sumber: id.pinterest.com)

\section{Matriks Pembobot Queen}

\section{a. Matriks Pembobot Spasial}

Berdasarkan Gambar 2, ketetanggaan antar provinsi di Indonesia dapat ditentukan. Provinsi yang bertetangga memiliki bobot 1 sedangkan provinsi yang tidak bertetangga memiliki bobot 0 , kemudian bobot-bobot tersebut dinyatakan dalam bentuk matriks seperti pada Gambar 5. 


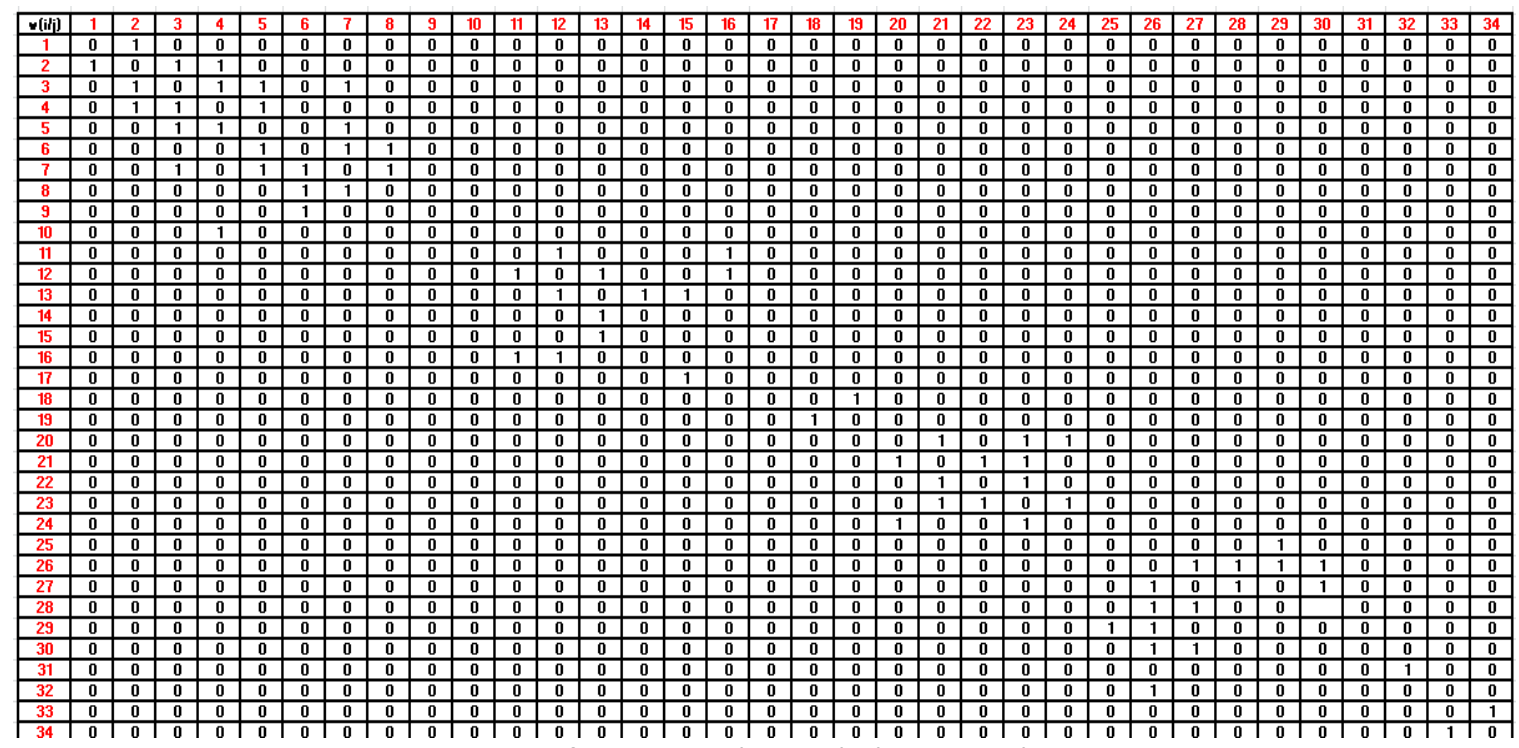

Gambar 5. Matriks Pembobot Spasial

\section{b. Matriks Pembobot Spasial Terstandardisasi}

Matriks pembobot spasial terstandardisasi ditentukan dengan cara menghitung jumlahan tiap baris pada matriks pembobot spasial lalu membagi elemen-elemen tiap baris dengan jumlahannya. Matriks pembobot spasial terstandardisasi yang terbentuk digunakan dalam perhitungan Indeks Baru. Gambar 6 menunjukkan matriks pembobot spasial terstandardisasi.

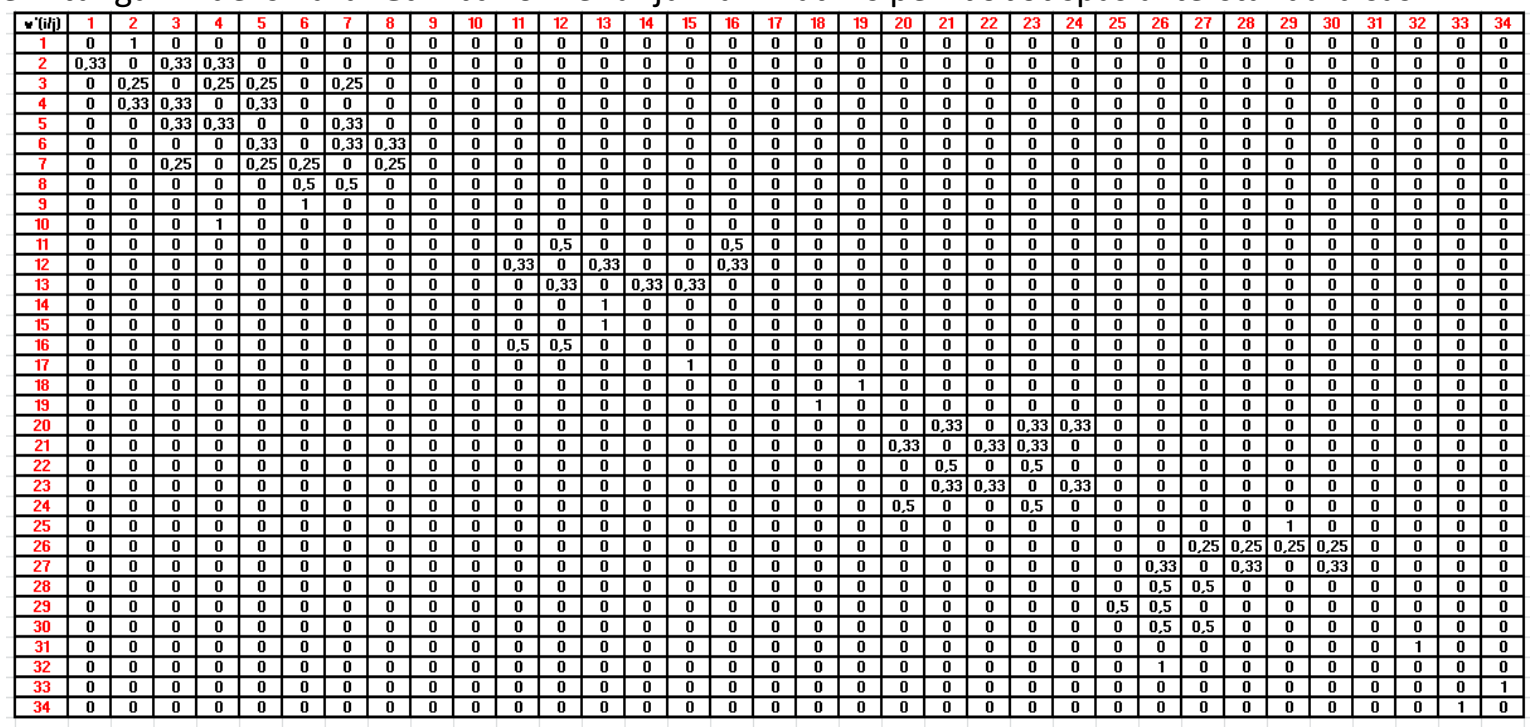

Gambar 6. Matriks Pembobot Spasial Terstandardisasi

\section{Indeks Baru}

Indeks Baru merupakan Indeks yang terbentuk dengan melihat hubungan antara Indeks Geary dan Indeks Moran. Griffith (1996) mencatat bahwa percobaan simulasi menunjukkan hubungan terbalik antara Indeks Geary dan Indeks Moran pada dasarnya bersifat linear (Sawada, 2009).

Indeks Geary dan Indeks Moran merupakan cara pengukuran autokorelasi spasial yang dilakukan secara global. Penelitian ini mendapatkan korelasi antara Indeks Geary dan Indeks Moran adalah kuat, yaitu -0.99149 dan signifikan dengan nilai- $p<0,05$. Melihat korelasi yang kuat dan signifikansi yang sama antara Indeks Geary dan Indeks Moran, maka dibentuk Indeks Baru dengan rentang $-1 \leq I_{B} \leq 1$ dan menggunakan persamaan (7). Berdasarkan persamaan (7) diperoleh nilai Indeks Baru yang ditampilkan pada Tabel 1.

Nilai Indeks Baru tersebut diperoleh dengan penghitungan menggunakan bantuan aplikasi $R$ dengan memasukkan data-data yang telah dimiliki menggunakan rumus Indeks Baru yang telah dirumuskan. Dalam penghitungan dilakukan pengulangan sebanyak 10.000 kali untuk mendapatkan nilai yang akurat. 
Tabel 1. Nilai Indeks Baru

\begin{tabular}{cc}
\hline Tahun & Indeks Baru \\
\hline 2010 & 0,46328 \\
2011 & 0,45734 \\
2012 & 0,4673 \\
2013 & 0,48122 \\
2014 & 0,49047 \\
2015 & 0,50176 \\
2016 & 0,49923 \\
2017 & 0,48824 \\
2018 & 0,48087 \\
\hline
\end{tabular}

\section{Uji Autokorelasi Spasial berdasarkan Metode Bootstrap}

Dalam pengujian autokorelasi spasial dilakukan hipotesis sebagai berikut:

$\mathrm{H}_{0} \quad$ : Tidak terdapat autokorelasi spasial antar provinsi

$\mathrm{H}_{1} \quad$ : Terdapat autokorelasi spasial antar provinsi

Dengan tingkat signifikansi $\alpha=5 \%$, kesimpulan yang diambil untuk $\mathrm{H}_{0}$ adalah dengan melihat besarnya nilai- $p$. Apabila nilai- $p>0,05$ maka $\mathrm{H}_{0}$ diterima. Hal ini berarti tidak terdapat autokorelasi spasial antar provinsi dan berlaku sebaliknya.

Dalam penghitungan metode bootstrap dengan pengulangan $B=10.000$ kali, diperoleh nilai- $p$ seperti pada Tabel 2. Tabel 2 memperlihatkan bahwa data tahun $2010-2018$ mempunyai nilai- $p<0,05$ sehingga $\mathrm{H}_{0}$ ditolak. Hal ini berarti bahwa terdapat autokorelasi spasial atau terdapat keterkaitan antara satu wilayah dengan wilayah lain yang bertetangga.

Tabel 2. Nilai-p menggunakan metode bootstrap pada Indeks Baru

\begin{tabular}{ll}
\hline Tahun & Nilai- $p$ \\
\hline 2010 & 0,0040 \\
2011 & 0,0054 \\
2012 & 0,0062 \\
2013 & 0,0036 \\
2014 & 0,0032 \\
2015 & 0,0020 \\
2016 & 0,0020 \\
2017 & 0,0026 \\
2018 & 0,0038 \\
\hline
\end{tabular}

\section{Resampling Berdasarkan Estimasi Densitas Kernel}

Tabel 3. Nilai- $p$ menggunakan Resampling berdasarkan Estimasi Densitas Kernel

\begin{tabular}{cc}
\hline Tahun & Nilai- $p$ \\
\hline 2010 & 0,0050 \\
2011 & 0,0056 \\
2012 & 0,0040 \\
2013 & 0,0036 \\
2014 & 0,0026 \\
2015 & 0,0018 \\
2016 & 0,0028 \\
2017 & 0,0030 \\
2018 & 0,0036 \\
\hline
\end{tabular}

Hasil resampling berdasarkan estimasi densitas Kernel ditunjukkan pada Tabel 3. Berdasarkan Tabel 3, nilai- $p$ pada setiap tahun menggunakan resampling berdasarkan estimasi densitas Kernel adalah 
kurang dari $\alpha=0,05$. Hal ini berarti bahwa $\mathrm{H}_{0}$ ditolak atau terdapat autokorelasi spasial pada IPM provinsi-provinsi di Indonesia tahun 2010 - 2018. Dengan kata lain IPM dari suatu provinsi mempengaruhi IPM provinsi yang bertetangga.

\section{KESIMPULAN}

Penelitian ini sudah menganalisis korelasi IPM Provinsi-Provinsi di Indonesia tahun 2010 - 2018. Berdasarkan hasil analisis dan pembahasan maka dapat disimpulkan bahwa Indeks Moran dan Indeks Geary memiliki hubungan/korelasi yang kuat sehingga dapat dibentuk Indeks Baru dengan rumus (Indeks Moran + 1 - Indeks Geary)/2. Berdasarkan hasil resampling menggunakan Metode Bootstrap dan resampling berdasarkan estimasi densitas Kernel ditemukan bahwa nilai- $p$ tahun 2010 - 2018 berkisar antara 0,001 0,006 yang berarti bahwa terdapat autokorelasi spasial atau terdapat keterkaitan erat antara IPM Provinsi dengan IPM Provinsi-Provinsi yang bertetangga. Dengan kata lain, bahwa antar provinsi satu dengan provinsi yang berbatasan memiliki kemiripan nilai IPM atau saling berkorelasi.

\section{DAFTAR PUSTAKA}

BPS. (2015). Indeks pembangunan manusia. In Badan Pusat Statistik.

BPS. (2019). Tabel indeks pembangunan manusia (metode baru). Retrieved from http://ipm.bps.go.id/data/provinsi/metode/baru

Gramacki, A. (2018). Bandwidth Selectors for Kernel Density Estimation.

Griffith, D. A. (1996). Spatial autocorrelation and eigenfunctions of the geographic weights matrix accompanying geo-referenced data. Canadian Geographer, 40(4), 351-367.

Jay, L., \& Wong, D. W. . (2000). Statiscal Analysis with ArcView Gis.

Modjo, M. . (2018). Identifikasi autokorelasi spasial pada laju inflasi di Indonesia Timur menggunakan local indicator of spatial autocorrelation (LISA) berdasarkan metode Boorstrap. Universitas Kristen Satya Wacana.

Nisa, E. K. (2017). Identifikasi spatial pattern dan spatial autocorrelation pada indeks pembangunan manusia Provinsi Papua Barat Tahun 2012. Jurnal At-Taqaddum, 9(August), 32.

Sarita, F. T., Setiawan, A., \& Parhusip, H. A. (2019). Analisis Indeks Pembangunan Manusia (IPM) Kabupaten/Kota di Provinsi Maluku Utara Menggunakan Indeks Geary C Berdasarkan Resampling Estimasi Densitas Kernel. Jurnal Teknik Informatika Dan Sistem Informasi, 5(1), 62-72.

Sawada, M. (2009). Global spatial autocorrelation indices-Moran's I, Geary's C and the general crossproduct statistic. University of Ottawa.

Setiawan, A. (2002). Resampling berdasarkan estimasi densitas kernel bivariat. 1(1).

Winsy Weku, Adi Setiawan, S. Y. (2012). Analisis pola spasial dan dinamika IPM Tahun 2006-2009 Propinsi Sulawesi Utara menggunakan metode spatial autocorrelation.

Zhukov, Y. M. (2010). Applied Spatial Statistics in R, Section 2 Spatial Autocorrelation Spatial Data and Basic Visualization in $R$.

Zucchini, W. (2003). Applied smoothing techniques part 1: kernel density estimation. Retrieved from https://staff.ustc.edu.cn/ zwp/teach/Math-Stat/kernel.pdf 